\begin{tabular}{|c|c|}
\hline DE GRUYTER & ECONOMIC THEMES (2014) 52 (4): 436-460 \\
\hline & DOI 10.1515/ethemes-2014-0027 \\
\hline
\end{tabular}

\title{
STRATEGIC MANAGEMENT ACCOUNTING ROLE IN THE PERFORMANCE MEASUREMENT AND CONTROL OF MULTINATIONAL COMPANIES
}

\author{
Ivan Marković \\ University of Niš, Faculty of Economics, Serbia \\ $\triangle$ ivan.markovic@eknfak.ni.ac.rs \\ Tatjana Stevanović \\ University of Niš, Faculty of Economics, Serbia \\ \tatjana.stevanovic@eknfak.ni.ac.rs
}

\section{UDC \\ 005.7 \\ Review paper}

Received:

02.07.2014

Accepted:

29.12.2014

\begin{abstract}
The type and amount of information needed by top management of large companies is primarily determined by the role of individual managers. Thus, managers at the top of the hierarchy in complex enterprises need information that is different from the information managers of individual divisions or strategic business units. Starting from these requirements, strategic management accounting has developed a number of ways to provide information aimed at shaping corporate strategy. In this regard, the paper will be discussed various aspects of performance measurement in multinational companies, as well as the tasks to strategic management accounting should meet within them. Bearing this in mind, the main objective of this paper consists in analyzing the importance of strategic management accounting is to successfully manage the performance of multinational companies. Adequate application of theoretical concepts and research methods chosen, the work is expected to extending domestic literatures in this field meet our economic releases to the role of strategic management accounting in the measurement and control of the performance of multinational companies.
\end{abstract}

Key words: strategic management accounting, measurement, control, performance, multinational companies 


\section{Introduction}

Multinational companies (MNC) are very strong companies whose economic power is often beyond the resources and the results of many countries. Characteristics of multinational companies primarily relate to the large geographical coverage, significant organizational interdependence and the ability of a coherent integration of the activities carried out in different countries.

Using the favorable conditions and comparative advantages offered by a specific geographical location and their integration in a multinational network of research and development, production and sales forces, available knowledge and accumulated experience of these companies are coming to the fore. In such circumstances, the primary tasks of strategic management accounting becomes coordination, control, resource allocation, performance measurement and management of currencies.

The concrete company, based on its own system driving forces and key success factors, selects a multidimensional performance measurement system that best presents selected business strategy. From a broader range of performance measures, which is immanent to the implementation phase of the strategy, the company chooses a rational system, which corresponds to the nature of its business activities, and selected business strategy.

\section{Methodology}

From the perspective of scientific methodology this is important methodological approach to the problem which is the subject of research. In the selection and application of specific methodologies of scientific research, we are guided by the need to the correct methodological and, to the extent possible, complete and accurate manner approach to the problem that is the subject of research in order to achieve the main goal of research: contribute to the understanding of the importance of the role of strategic management accounting in the measurement and control performance of multinational companies. In accordance with the subject matter and research goals, during the survey will be used following the scientific method.

In order to establish the basis of the research of this problem the empirical analysis of the role of strategic management accounting in the measurement and control performance of multinational companies will be applied. First the method of deduction will be applied in order to get the desired response, while in the later stages of the research the inductive method will be applied in order to reach new conclusions and hypotheses. 
Paper (Kaplan, Norton, 2008) concluded that a new market-oriented strategy and its adjusted organization of multinational company require a new performance measurement system. In this regard, he emphasized the importance of the Balanced Scorecard (BSC) because of its ability to link strategy with appropriate performance measurement system, and thus enables the linking strategy of profit center with responsibility of their managers.

Adam Nurmohamed, Heidi Kwok, Pearl Law, Mandy Wong and Sean Ma (2010) in their case presentation discuss companies that are the world's top 3 in integrated oil, gas and petrochemical. They are particularly concentrated in the development process launched in 1994 by renaissance solutions senior-level executive leadership team (ELT) guided interviews to extract ELT ideas about BSC developed objectives \& measures for four BSC perspectives. Key findings of their study include: operational improvements, customer base increase, dealer partnerships, knowledge base, profitability and competitive advantage.

In 2011 Emir Kasseyev (prezi.com/.../mobil-usmra-linking-the-balanced-s), Harvard Business School, follows the introduction of the Balanced Scorecard in example of Mobil Corporation Fairfax companies, in Virginia with operations in more than 100 countries.

The authors will be in this research directed towards such an approach to establishing links between business strategy and appropriate performance measurement system that starting from the formulated strategy recognizes the key success factors and driving forces system for value creation of multinational companies. The end result of this approach is significantly streamlined and made a concrete performance measurement system that matches the chosen business strategy. In order to fully meet the requirements imposed by the object of study for this research will be applied and the comparative method, while a synthetic method imposed as to consolidate the previously mentioned method, and the shaping of a unified whole. Therefore, this paper will apply a combined system of more scientific methods, with the prioritization system analysis method which is based on three basic principles, objective analysis, and the truth of the evidence and scientific reliability of the methods.

\section{Specifics of Multinational Companies}

Only a century ago, it was generally accepted that the prosperity of a nation depends on the management of natural resources such as land, minerals or labor, which is the nation gained a comparative advantage over others with less wealth. In today's global economy is the most visible trend of business just increasing globalization of the market of material goods and services around the world, so the company can get to the resources, wherever they are, in a cost effective manner (Marković, 2013). The main carrier of this process are transnational companies - MNC, which is a phenomenon developed in response 
to the expressed human need to organize people, money, resources and technology on a global basis. There is also a reason for their rapid growth, because there is no institution that would better serve the purpose of them (Todorović, Marković, 2001). Contemporary processes of globalization, under the influence of MNC's, lead to more equalize the conditions of doing business in various national economies, leading to the formation of the world economy as a single entity. The wide network of MNC makes the embryonic form of the central nervous system of the emerging global economic order, as well as a form of global economic institutions is an instrument of transition in the global economy.

Their great power based on the enormous size and activities on a global scale, especially in the social influence that stems from it; internationalization of all phases of operations; centralization of decision-making; monopoly control of the world's raw materials and energy; as well as the great potential of scientific and technical development, including the ability to attract and engage a number of scientific staff from around the world. Thus, MNC's are still the most important factor in the world economy, which controls more than $70 \%$ of world trade and $80 \%$ of the world's financial potential. The most dynamic sectors of the economy are broadly transnational and have an interest in maintaining an open international economic system (Marković, 2003). The expansion of MNC's has led to the growing integration of the world economy in which their business is increasingly limited by national boundaries, so that the factors of production and goods to move freely, which allows for the reproduction cycle of global capital freely fertilization (Marković, 2003).

It is characteristic, for example, the Japanese company „Toyota” one-third of the total production generated from its 25 companies located in America, Europe and Asia. Exports about $45 \%$ of its production realized in Japan. Through its regional network of Asian imports diesel engines from Thailand, the Philippines transformers, heaters, etc. from Malaysia. American company „IBM" in the field of information technology, $41 \%$ of its sales realized in the North American market, $30 \%$ in Europe and $9 \%$ in Asia. „Canon“ is realized $30 \%$ of its production in North America, $29 \%$ in Europe and $37 \%$ in Asia. For companies that have a relatively small domestic market, such as the giant Dutch electronics industry „Philips“ or Swiss food colossus of an industry, it is crucial exit out of the national market and the expansion of its activities on the planet. For this reason, MNC's locate their center of activity everywhere can realize the most effective combination of technology, capital and labor to produce the most profitable and launch their products. They are trying to infiltrate and in the periphery of the world economy, the interest of the city to spatially decentralized production operations, seeking more profits and lower wages. As a consequence, the emergence of transnational unwieldy empire whose business scope often exceeds the gross national product of many countries. 
On the basis of the content of MNC is a strategy that foreign investment is being made, rather than in the form of the loan capital in the form of capital and entrepreneurial business to be managed mainly from the country of origin of the company. Foreign direct investments in modern developmental stages function as a key development factors and the international trade and technological progress have become the main mechanism for the global economy. Common modes of transmission activities of MNC's in other countries, in addition to FDI as the most important ways: exports of goods, sales of licenses, portfolio investments, joint ventures, contractual arrangements and know-how. In such circumstances, the companies strive to become a global, primarily due to the inclusion in the global market of material goods and services, to oppose competition in the domestic market, hedging and cost per unit of product. In addition, the development of productive forces, as a result of the scientific and technical revolution, led to the fact that in some industries it is impossible to organize the production of which would be profitable, if it only works for the national market. To be effective, corporations seek to ensure the good market position, increasingly insist on quality, technological innovation, with particular attention to attach a global strategy and development. In the struggle for dominance in the market, do not shy away from the use of various noneconomic, even illegal activity, that they an effective and fast way to provide global dominance.

These economic agents are much more effective than national companies from a revenue and research activities, thus creating a new ideology of global business and play an important role in the transformation of the structure of the capitalist mode of production. In its business activities are often elusive to the regulations and customs of national countries, with global corporations at a disadvantage, because, according to her parts of the national economy, and it is to the nation-state - a unit. In this important role of financial capital as the union of industrial, banking and commercial capital, which transcends national boundaries and mobilize capital on a world scale, and the concept of global business that has been accepted MNC is the treatment of the whole world as a single market. In this way, adaptation to specific requirements and tastes of each region is much smaller, leading to significant savings in operating costs. This was achieved by modeling and unification of customer needs through massive use of information technology and the skillful application of advertising in the media. In a broader sense, it is a major impact on the MNC system of socio - cultural values, lifestyle and design of modern information civilization.

Based on a comparative consideration of the size of the gross domestic product (GDP) of the countries and the amount of the revenues of the world 's largest MNC's, it can be seen that at the top of the U.S. GDP worth U.S. \$ 11.713 billion, more than double the second-placed Japan. However, among the 
first one of hundred leading economic entities in the world in 2012, not the state, but MNC, with one of the largest U.S. corporations, „Wal -Mart Stores” with revenue of 447 billion U.S. \$ in 27th place, larger and stronger than economy of Norway, Saudi Arabia, Denmark, Poland and Indonesia. After the above mentioned countries, appears MNC „Exxon Mobil“ with revenue of 420 billion U.S. \$. The automotive giant „General Motors“ at the 39th place with U.S. \$ 195 billion, ahead of the value of GDP of Finland, Ireland, Portugal, Iran and Hong Kong, while Taiwan and Argentina by economic power can find between MNC „Ford“ and „General Electric”. Petroleum Corporation „Chevron" with revenue of 222 billion U.S. \$ in a similar economic level as Malaysia and Israel, and in front of the Venezuelan economy, the Czech Republic, Hungary and Singapore. On the list of leading as economic entities in the world, including banks, „Citigroup“ and „Bank of America“, oil corporation „Conoco Philips“ and manufacturers of IT equipment „IBM“ and „Hewlett Packard". The data show that the importance of MNC growing and their activities are increasing the share of total world GDP. However, although MNC compared to other businesses, including a number of nation-states, characterized by a series of benefits arising from the cumulative effects of several factors, such as a monopoly in the market and in the field of technology, capital mobility, possess enormous financial power and increasing the reserve army of labor tamed uncertainty and the constant threat of unemployment, in all their activities strongly affect consumers themselves.

With the mobilization and active participation of NGOs, supported by the pressure of public opinion, MNC's are forced to listen to the voice of the other, and to reorganize its business in a socially responsible and environmentally sustainable manner. These needs are noted and famous American economist of the Austrian origin Peter Drucker (1909-2005), which expressed the position that does not mean that corporations should be free of their social obligations. On the contrary, they should be so organized that automatically fulfill their social obligations in the act of seeking to fulfill their own best interests. The human world of ecology, human rights and other things, for a dignified and quality life necessary qualifier, reached the required level of awareness and understanding of the essential causes and background of social phenomena and trends. The consequence is more frequent and more organized struggle against the negative consequences of corporate behavior. Power boycott buying certain products of selected corporations and other forms of expression of disagreement with the behavior of these MNC's that the pursuit of profit neglect the social and ethical norms, are able to strongly influence the change of their irresponsible behavior. 
Табле 1. The world's top 10 non-financial MNC's, ranked by foreign assets, 2012 (millions of dollars and number of employees)

\begin{tabular}{|c|c|c|c|c|c|c|c|c|c|c|c|}
\hline & & & & & & & & & Emp & ment & \\
\hline 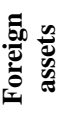 & $\bar{Z}$ & نَّة: & 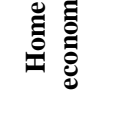 & 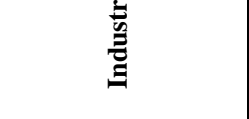 & 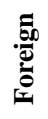 & हूँ & 量 & हूँّ & 总 & 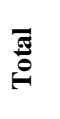 & $\frac{\widehat{e}}{e^{\infty}}$ \\
\hline 1 & 2 & $\begin{array}{c}\text { General } \\
\text { Electric Co }\end{array}$ & US & $\begin{array}{c}\text { Electrical \& } \\
\text { electronic } \\
\text { equipment }\end{array}$ & $\frac{n}{\infty}$ & 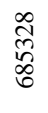 & $\begin{array}{l}\text { q } \\
\text { in } \\
i\end{array}$ & $\begin{array}{l}\stackrel{2}{2} \\
\text { I }\end{array}$ & 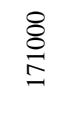 & $\begin{array}{l}8 \\
8 \\
8 \\
0 \\
0 \\
0\end{array}$ & $\begin{array}{l}n \\
\tilde{n} \\
n\end{array}$ \\
\hline 2 & ले & $\begin{array}{l}\text { Royal } \\
\text { Dutch } \\
\text { Shell plc }\end{array}$ & UK & $\begin{array}{c}\text { Petroleum } \\
\text { expl./ref./distr. }\end{array}$ & $\begin{array}{l}\infty \\
\check{\hat{\sigma}} \\
\hat{\sigma}\end{array}$ & 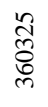 & 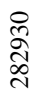 & $\frac{n}{\frac{n}{\sigma}}$ & $\begin{array}{l}8 \\
8 \\
\end{array}$ & $\begin{array}{l}8 \\
\frac{8}{\infty}\end{array}$ & $\begin{array}{l}0 \\
\stackrel{0}{0}\end{array}$ \\
\hline 3 & ส & BP plc & UK & $\begin{array}{c}\text { Petroleum } \\
\text { expl./ref./distr. }\end{array}$ & 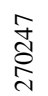 & $\frac{\mathfrak{2}}{8}$ & $\frac{0}{\widehat{\delta}}$ & $\begin{array}{l}\infty \\
\infty \\
\infty \\
\infty\end{array}$ & $\begin{array}{l}n \\
\infty \\
\infty \\
8\end{array}$ & $\begin{array}{l}\S \\
\infty \\
\infty\end{array}$ & $\begin{array}{l}\infty \\
\tilde{\infty}^{0}\end{array}$ \\
\hline 4 & $\curvearrowright$ & $\begin{array}{c}\text { Toyota } \\
\text { Motor } \\
\text { Corporation }\end{array}$ & Japan & Motor vehicles & 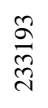 & $\begin{array}{l}\text { F } \\
\text { o } \\
\text { m }\end{array}$ & 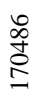 & 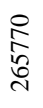 & 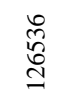 & 㐫 & 垈 \\
\hline 5 & $\stackrel{\infty}{\sim}$ & Total SA & France & $\begin{array}{c}\text { Petroleum } \\
\text { expl./ref./distr. }\end{array}$ & 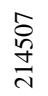 & 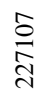 & 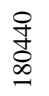 & \begin{tabular}{l}
$\hat{\infty}$ \\
\multirow{\sim}{*}{} \\
$\stackrel{\sim}{N}$
\end{tabular} & $\frac{\widetilde{\Xi}}{\mathcal{J}}$ & $\frac{\stackrel{0}{1}}{\hat{a}}$ & $\begin{array}{l}n \\
\infty \\
\infty \\
\infty\end{array}$ \\
\hline 6 & ケ & $\begin{array}{c}\text { Exxon } \\
\text { Mobil } \\
\text { Corporation }\end{array}$ & US & $\begin{array}{l}\text { Petroleum } \\
\text { expl./ref./distr. }\end{array}$ & $\underset{\stackrel{q}{d}}{\stackrel{q}{d}}$ & $\underset{\substack{n \\
m}}{\stackrel{n}{m}}$ & 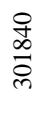 & 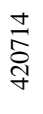 & 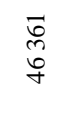 & 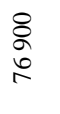 & $\stackrel{+}{b}$ \\
\hline 7 & $\infty$ & $\begin{array}{l}\text { Vodafone } \\
\text { Group Plc }\end{array}$ & UK & Telecommunications & ڤి & 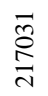 & $\begin{array}{l}n \\
8 \\
\text { Vू }\end{array}$ & $\begin{array}{l}\underset{N}{N} \\
\stackrel{2}{R}\end{array}$ & 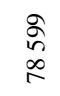 & $\underset{\infty}{\infty}$ & $\stackrel{+}{\&}$ \\
\hline 8 & ช్ర & GDF Suez & France & $\begin{array}{c}\text { Utilities } \\
\text { (Electricity, gas and } \\
\text { water) }\end{array}$ & 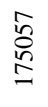 & $\frac{\hat{o}}{\stackrel{i}{*}}$ & $\begin{array}{l}n \\
n \\
\infty \\
\infty\end{array}$ & $\underset{\text { J }}{\stackrel{\text { J }}{二}}$ & $\stackrel{\infty}{\stackrel{0}{\varrho}}$ & 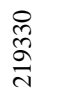 & ñ \\
\hline 9 & 5 & $\begin{array}{l}\text { Chevron } \\
\text { Corporation }\end{array}$ & US & $\begin{array}{c}\text { Petroleum } \\
\text { expl./ref./distr. }\end{array}$ & $\begin{array}{l}n \\
\infty \\
\infty \\
\infty \\
n\end{array}$ & $\begin{array}{l}\text { } \\
\stackrel{\text { సे }}{\text { సે }}\end{array}$ & 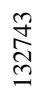 & 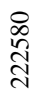 & $\frac{\infty}{\infty}$ & 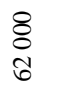 & ñ \\
\hline 10 & t & $\begin{array}{c}\text { Volkswagen } \\
\text { Group }\end{array}$ & Germany & Motor vehicles & $\begin{array}{l}0 \\
\substack{0 \\
\infty \\
n}\end{array}$ & $\begin{array}{l}\hat{n} \\
\text { ò }\end{array}$ & $\frac{\grave{\jmath}}{\sigma}$ & 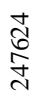 & $\begin{array}{l}\text { ¿ } \\
\text { ¿े }\end{array}$ & के & $\begin{array}{l}n \\
\infty \\
\infty \\
n\end{array}$ \\
\hline
\end{tabular}

Source: http://unctad.org/

In our business, MNC occurred, the multitude of incidents around the world, the consequences of which have multiple affected by the environment and the local population in the region, most notably to 1984 , When in the Indian city of Izopal poured toxic gas corporation „Union Carbidge“. Within three days, 7,000 
people died and thousands were injured. Today, more than 20 years later, over 100,000 people suffer from chronic diseases, and children born with birth defects. The above MNC refused to recognize the jurisdiction of the courts in India, in which the members of the affected communities for justice. In Kenya, a Canadian corporation „Tiomin“ recently came into conflict with the local community, when its actions threaten forests of this community for centuries considered holy. Also, in December 2003., the area „Rupokwu“ in Nigeria suffered extensive damage when a broken pipe pipeline corporation „Shell“, a waste oil contaminated water and destroyed the lake with fish, which is the majority of households in the agricultural area was left without a source of income and drinking water. From these examples we can see that MNC's often work in areas that are rich in natural resources, but are not economically developed, where they exploit the environment and the local population, affecting even their move, thus endangering their cultural heritage and identity.

There are other examples of similar misdeeds of some MNC's, which are still ongoing, but if the corporation intends to maintain its position of the dominant institutions in society, will have to be seen as useful in general. It requires you to use your influence for the improvement of the whole human community, not only because of its ultimate goals. However, with the current economic structure of many externalize social and environmental costs of doing business, the two efforts are often in conflict. The goal should be to connect with social corporate profits. Some corporate executives have realized, and the president, „Du Pont“, Charles Holliday Jr., points out that there is no success in business in the twenty-first century if the company fail or global ecosystems continue to deteriorate. Corporate Responsibility essentially means that corporations should behave in an environmentally sustainable and socially beneficial way: to prevent environmental degradation, to create useful and healthy products to treat workers and communities act justly and fairly and that their enormous influence used to improve the welfare of the entire society. In this way, corporations would benefit and the market as a more complete consumer satisfaction creates conditions for better market reputation.

The process of globalization, especially the IT achievements and educational development of social consciousness, creates more ethically minded consumers who actually buy on the scale of its value. Moreover, if MNC labeled as socially responsible, thereby reducing the risk of possible attacks activists of certain organizations, which could cause the stain brand or influence the loyalty of consumers. Bad publicity in public is the most effective tool in the effort to MNC corrects their behavior. As they felt „,something”, „Nike“, „Coca - Cola" and others, boycott, workers strikes, litigation and negative advertising can achieve a direct impact on the ultimate goal of the company. However, although the ecological and ethical implications of the initiatives outlined clearly useful, the primary motive of the corporation's financial nature. Thus, 
the general director of MNC „General Electric”, Jeffrey Imelt explained to initiate a plan of ecological view: „We start with ecological view not because it is fashionable or because it's moral, but because it will accelerate our growth and make us more competitive". For this reason, a listed corporation hopes to by 2015 was to have U.S. $\$ 20$ billion in revenue from product of ecological view. Many other MNC's in similar ways trying to reconcile social and corporate interests, and „IBM”, „BP”, „Exxon Mobil“ and „Du Pont“ by reducing waste production lowers costs for a hundred U.S. \$, thereby increasing competitiveness and acceptability their products to market. Learning from bad experience negative reputation in the market, due to the exploitation of poorly paid workers, the corporation "Nike“ trying to make non-toxic shoes that will be able to recycle and thereby show themselves in a new light. Of course, in the short term, the greater corporate responsibility does not always bring higher profits because most of the measures for pollution control and employee benefits costs are added. However, viewed in the long run, greater accountability can help corporations to beat rivals by being one step ahead of the strict regulations, which will reduce the use of costly inputs and attract money caring investors and consumers. For other corporations, which do not follow the transformation of the market and do not follow the path of a sustainable society, the choice will be all the more risky.

MNC's have their levers of power in the hunt for profit, to traverse the planet on which they affirmed the global dimension of capitalism. In addition, certain phenomena in the process of internationalization yielded a qualitatively higher level, which enabled the powerful process of international integration and the emergence of the global economy, whose essence is the realization of national interests and economic expansion, primarily home countries. In the course of further development of the MNC's new strategy of increased engagement in the development of new technologies, which were able to in the current crisis not only maintain but also increase the level of their profit margins, while the effects of the crisis successfully transferred to other actors of the world economy: workers and the economy are developed countries. Also, certain corporations with distinctive long-term strategy recognized the need of consumers for ethically and environmentally responsible approach to business and more often adjust their behavior in this regard. However, regardless of the occurrence and need a more responsible corporate behavior, the great power of MNC's still holding my neck the whole world. Even transnational capital is able to stimulate the crisis on a global scale, moving to only 1-2 \% of its weight because any change in the parity of the world's currencies and to ignore the nation-state as a secondary force (Marković, 2008). With astonishing amounts of money, economies of scale, the ability to manipulate the prices of goods and even the power to determine the policy of governments, MNC's are the real masters of the planet. 


\section{Dimensions of Performance Measurement of Multinational Companies}

The complexity of multinational companies significantly complicates the task of strategic management accounting in the field of measuring their performance. In doing so, these tasks are significantly different from one multinational enterprise to another, which prevents a single universal prescription for solving the problem. Therefore, we can safely conclude that strategic management accounting in any multinational company must match the unique information needs of its central management. In this regard, it must be adjusted precisely measure the performance needs of central management in multinational companies.

Due to the fact that the interdependence of subsidiaries in multinational companies is extremely important, any Subsidiary, especially central management must be thoroughly versed in the operations of other subsidiaries. In doing so, these circumstances necessitating the appropriate non-financial indicators. For example, information about the performance of individual product lines is necessary for the global planning of production and sales efforts to be undertaken around the world. Also, information about the lack of order in one region is an important foundation for the planning of production in other regions of the world. We note also that the information on customer complaints about the quality from anywhere in the world is of particular importance for corporate research and development. The cost of external defects that occur while, affect not only the planning of production in factories, but also the introduction of services that subsidiaries must provide customers around the world (Milićević, 2003).

On financial performance measures in multinationals is also associated with specific characteristics. The profit subsidiaries are not the most important point of focus of corporate management. One could say that this interdependence of subsidiaries within the global organization. Consequently, the profitability of individual global product line is much more important than the profitability of certain subsidiaries. Thus, investment in productive plant in one country affect what should be sold in another country.

The wide geographical coverage entails centralized decision-making on selling prices in multinational companies. Very often in this connection forms a „cost - plus" pricing strategies, which on the one hand, responsibility for corporate profitability attributed to the top, while, on the other hand, allows subsidiaries to some extent affect the determination of the sales price.

Strategic management accounting information can provide its central management of multinational company's good support to integrate subsidiaries in centralized organizational milieu and establish highly coordinated 
relationships between them. This role strategic management accounting can successfully play exclusively composing meaningful financial and non-financial performance measures.

The correlation between financial and non-financial performance measures at all levels of the organizational structure provides a complete picture of the results achieved during the implementation of formulating developed company's strategy and is, therefore, necessary use of both. The topmanagement and senior levels of the organizational hierarchy should follow not only the financial measures that tell the results of past decisions, but also nonfinancial measures as predictive indicators of future performance. Similarly, staff at lower levels of the organization must understand the consequences of their financial and operational decisions.

The emergence of innovative disruptive technologies and globalization have changed the basic assumptions of the business, and of crucial importance for achieving sustainable competitive advantage becomes the company's ability to mobilize and exploit intangible assets, which will allow you build customer loyalty, serving new markets and segments, timely development of an innovative high-quality products and services at low costs and employee involvement in a process of continuous improvement of capacity, quality and response time. For these reasons, the reporting model, which relies only on the financial perspective, it must be extended valuation of intangible and intellectual assets, which contribute most to success in today's competitive environment, which is related to the reliability of suppliers, internal competencies, skilled workforce and loyal customers (Simons, 2000).

The integrated performance measurement system as a key part of the organizational infrastructure, involved in all aspects of the management of the business cycle, ranging from strategy formulation, through its communication through organizational structure, developing and implementing tactics of its implementation, and to develop control systems for monitoring performance in achieving strategic goals. Performance must be assessed for deterministic when appropriate strategic options, they must follow the audit strategy, their communications and develop tactical objectives. Therefore, it is necessary integrated approach to performance measurement that goes beyond its traditional role based solely on feedback control (Nanni, Dixon, Vollmann, 1992).

Successful implementation and development of an integrated performance measurement system is based on the respect of the following basic determinants (Parmenter, 2007):

- creating value for stakeholders,

- the role of senior management and employees

- correlation measurement, reporting and improvement of performance and

- link performance measures to the chosen strategy. 
The importance of an integrated performance measurement system is minimal if it is not associated with the current key success factors of the company, the chosen strategy and the ultimate goal of creating value. Integrated system, or as they are also called the „strategic performance measurement system", trying to integrate the strategic goals and business initiatives through the translation of strategic directives into guidelines for everyday activities. A well-designed and developed a strategy requires its proper implementation. As the strategic directions of change over time, the main task in these changes is to determine the critical success factors, which is actually determined by the performance and capability of the company. Development of an integrated performance measurement system just necessitates defining factors that reveal the bedrock of strategy execution and value creation of the company. Thus, the number of performance measures can significantly reduce a company's management to focus on those most important and focus on actions that have the greatest impact on the successful implementation of strategic goals. Practice has shown that there should be between two and eight key success factors. Once you determine the right key success factors, creating a multidimensional performance measurement system is greatly facilitated.

Each of the identified factors of competitiveness, which may relate to the reduction of costs and the improvement of manufacturing processes, the level of technological leadership, reliability, innovation, timeliness, quality, flexibility, degree of customer satisfaction and so on. Usually requires several carefully selected performance measures (Shank, Govindarajan, 1993). If as a strategic objective lineup technology leadership in the industry, matching candidates for critical success factors are: the development and maintenance of technological capabilities, providing enough funds for projects in the field of technology with market potential, quickly launch development projects in the market and so on. Their corresponding performance measures could be the following: Open Positions Research and Development, Jobs Opportunities, the ratio of accepted bids, offers rational maintain technological capabilities, the percentage of failed projects and the percentage of revenues from products younger than 24 months, during coverage of the market, period harmonization projects in the area technologies with market potential, while the percentage of the launch of development projects on the market (Dressler, 2004).

Developing strategies ultimately leading to tangible performance indicators for each success factor, with the ideal produces 30-60 potential performance measures. If the reliability is considered an important strategic factor of competitiveness, the system incorporates measures such as the percentage of products returned by customers or the rate of timely delivery as appropriate indicators of reliability of products and services. Strategic factor of timing in response to consumer demand requires accurate measurement of time to carry out all necessary activities, ranging from communication with suppliers, 
through procurement, production and internal logistics, to the delivery of the required products to customers. Achieving the required level of quality, which intensified in its relevance, a need for continuous monitoring of the performance of products and services, primarily through measuring the degree of satisfaction of customers/consumers, the number of their complaints, the percentage of warranty repairs, or, again, the rate of waste, defects and product returned the refinement (Shank, Govindarajan, 1993).

After identifying the key success factors immanent to particular companies, access to identify priority measures. This effectively means that all measures identified through the development of strategies analyzed in terms of their compliance with the set strategy and adds value to the company, as shown in Figure 1 .

Figure 1: Identification of the priority performance measures

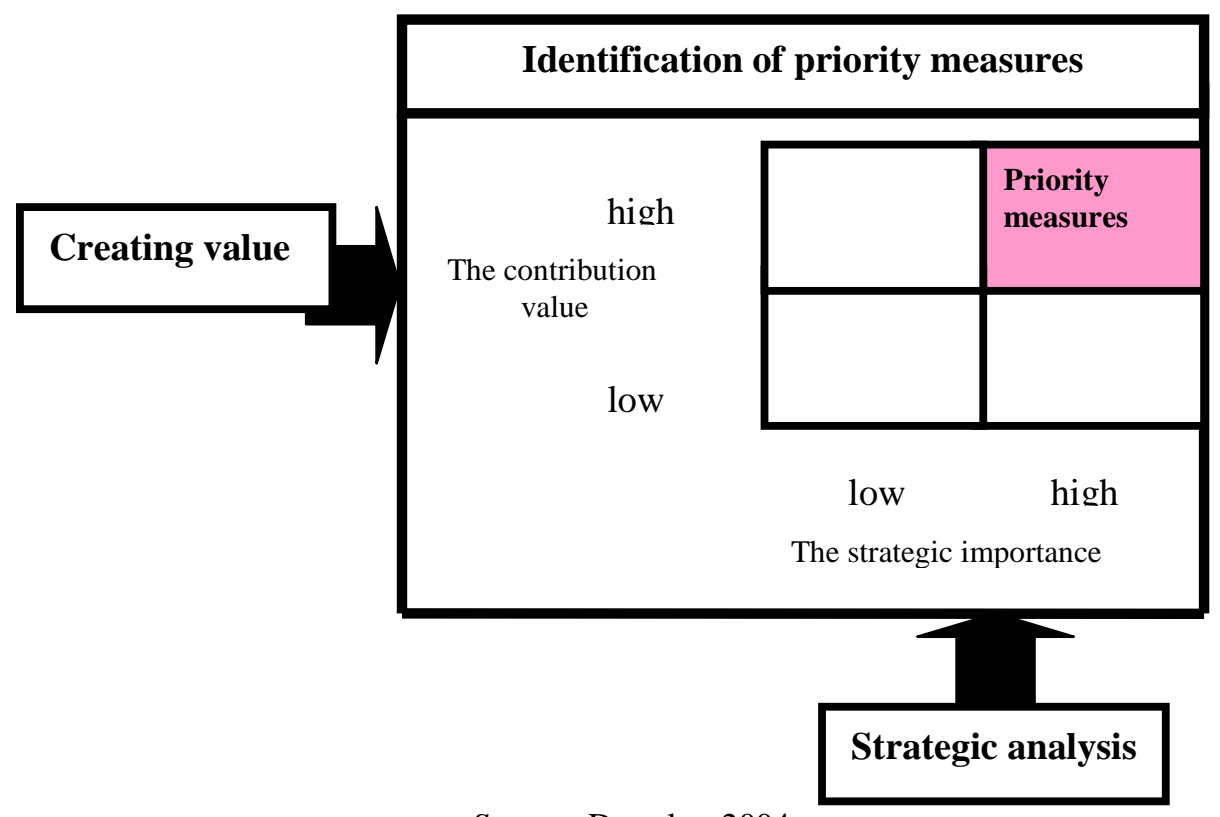

Source: Dressler, 2004

The primary goal of strategic analysis consists in the creation of potential performance measures that are closely associated with the business vision, strategic objectives and key success factors of the company. Their strategic importance is assessed as low or high. Analysis of value creation focused on monitoring the contribution of potential performance measures to value creation of the company, which also can be high or low. By assessment of each potential indicator in relation to its contribution to the creation of value and strategic importance achieved the synergy of the strategic focus and values of 
the company. In this way it is done selection of the priority performance measures, i.e. measures which have strategic importance and contribution to value creation at a high level.

In addition, it is necessary to test the criteria of „measurable“ and „controllability“, not relevant to the definition of priorities, but if they are not met, the potential measures are dismissed automatically. In some cases, internal information systems not perfected for generating of required data related to, for example, the interpretation of the cost of the dimensions of the products or customers, or operational measurements such as work in progress by organizational units. Some measures, such as relative market share, it is impossible to determine due to the deficiency of data on the market size. Controllability criterion is met if the measures contain at least one variable in that it can influence, such as relative indicators, like revenue growth of the company in relation to the growth of gross domestic product, or the price changes in share price of the company in relation to a stock exchange index.

In doing so, establishing a correlation between financial and non-financial performance measures within the control system is an imperative, given that the realization of superior performance is only possible by combining the optimization of financial performance and the implementation of non-financial objectives.

3. Information on Support Strategic Management Accounting to Performance Measurement and Control of Multinational Companies in the Example of Mobil Corporation

Mobil North America Marketing and Refining (NAM\&R or USM\&R) is based in Fairfax, Virginia, with operations in more than 100 countries, in addition to Exxon and Shell, was one of the three largest producers of oil, gas and petrochemicals. Mobil's stated strategic vision was ,to be the best integrated refiner marketer in the United States by efficiently delivering unprecedented value to customers". Exxon Mobil Corporation or ExxonMobil is an American multinational oil and gas company formed on 30 November 1999 the merger of Exxon and Mobil USM\&R company.

Return on capital employed in Mobil Corporation in 1995 was $12.8 \%$, which was the fourth score among the 14 largest oil companies; annual increment share of $19.1 \%$ on average for the period 1991-1995 is the largest compared to the other oil companies. Summary data on the sales and profits of the period 1993-1995 are given in Table 2.

\footnotetext{
${ }^{1}$ Example was taken from Simons, R. 2000., Performance Measurement and Control Systems for Implementing Strategy, Text and Cases, Prentice Hall, New Jersey, p. 544-561.
} 
Table 2. Summary data on sales and profits of Mobil Corporation

\begin{tabular}{llll}
\hline \multicolumn{4}{c}{ Summary financial information, 1993-1995. (in mil. \$) } \\
\hline & 1993. & 1994. & 1995. \\
\hline \hline Revenues & $\$ 63,975$ & $\$ 67,383$ & $\$ 75,37$ \\
Profit from operations & 2,224 & 2,231 & 2,846 \\
Expenditure on research and capital expenditures & 3,656 & 3,825 & 24,802 \\
Capital employed at the end of the year & 25,333 & 24,946 & 4,268 \\
The ratio of the loan capital & $32 \%$ & $31 \%$ & $27 \%$ \\
The rates of return on: & & & \\
$\quad$ Equity & $13,2 \%$ & $13,2 \%$ & $16,2 \%$ \\
$\quad$ & $10 \%$ & $14 \%$ \\
sector average & $10,2 \%$ & $10,3 \%$ & $12,8 \%$ \\
average capital employed & & $8,1 \%$ & $10 \%$ \\
sector average & &
\end{tabular}

Source: Simons, 2000

In 1992 Mobil Corporation was in the 12th place on the profitability of the 13 oil companies in the United States. The turn began in 1993 that profit and return on equity will soon overcome the sector average. The functional organizational structure of Mobil Corporation existed until in 1994. Group to supply purchased crude oil and transported to a refinery. Production function in refineries processed crude oil into fuel, kerosene, heating oil, diesel, jet fuel, lubricants and petrochemical intermediate. Service dispatch transported petroleum products through pipelines and barges and trucks to regional terminals across the country. Managers of terminal received, stored and managed inventory and distribute them to retailers and distributors. Marketing function determined the packaging, distribution and sale of Mobil products through wholesale and retail to end users.

In the early nineties, Mobil faced with stagnating demand, growing competition and limited capital for investment in capital- intensive business. Bob McCool, vice president of USM \& R division, recalls: "in 1990 we have not earned anything. In fact, we even lost 500 million cash. Expenditures and the capital have doubled, margins have fallen, as well as sales volume." McCool is the next few years dedicated to ensuring that the company recovers and stop the outflow of money, which he managed, faced with how to generate future growth. By examining the business environment during 1993 was found that employees considered internal reporting requirements, administrative processes and top-down policy by limiting factors of creativity and innovation. Customer relationships are casual, while employees work only as long as necessary to achieve solid results of its business units. McCool, with the help of external consultants initiated a major study of business processes and organizational efficiency, on the basis of which he concluded that it was necessary to focus on 
customers, follow their needs and desires, and strive to completely satisfy it. In 1994 was implemented the decentralization of decision making for managers and employees who want to be closer to customers. USM \& R were reorganized into 17 primary business units and 14 service companies. Core business units are included:

- unit of sales and distribution,

- integrated units of processing, sales and distribution

- units of specialized products and processes.

McCool commented on the need for reorganization as follows: „Too much we have grown as a functional organization. We have a huge administration and we must put its costs under control. But the most important thing is to focus on customers. We have to teach everyone in the organization cannot be a little better do their job, but all the energy focused on a better offer of Mobil products and services to customers ." Brian Baker, vice president of USM\&R continued: „We were a big centralized organization that has strayed from its customers. We did not have the ability for rapid change with new marketing programs."

Reorganization of USM\&R took place simultaneously with the newly developed customer segmentation strategy. Historically, Mobil, like other companies, trying to maintain growth and sales volume by placing the full range of products to all segments of customers. Marketing petrol group conducted a study that revealed five segments among buyers of fuel:

- $18 \%$ of Road Warriors, mostly middle-aged men of high incomes that exceed 25,000-50,000 miles a year, buying premium fuel by credit cards, buy sandwiches and drinks at the store, and sometimes the car wash in the laundry;

- $16 \%$ of true blues, usually men and women with moderate to high incomes who are loyal to the brand, and sometimes a separate cell, often buying premium fuel and pay cash;

- $27 \%$ of F3 generation, constantly mobile men and women, of which half younger than 25 years, crossing a significant mileage and abundant food in the restaurant at the pump;

- $19 \%$ of homebodies, housewives transporting children during the day and use any station based in the city or along their routes and

- $20 \%$ of price shoppers, customers who are not loyal to any brand or special pumps and rarely buy premium fuel, often with small budgets.

USM\&R management decided to focus efforts on the first three segments (61\% of all customers) and not trying to attract unfair customers and pricesensitive customers. The new strategy requires a commitment to improving the service stations to be able to offer a fast, comfortable and safe service to targeted segments. This requires a change in the role of Mobil stores (called c- 
store). Currently, c-stores are restaurants designed to attract impulse purchases of motorized customers.

Commitment to improving of services indicates an attempt to incorporate an element of differentiation in the strategy of focusing, which is also an important indicator of the key success factors of this strategy, the quality and innovation.

Pursuant to the aforementioned, USM\&R has identified a new set of driving forces associated with the organization in the most general sense of the word, whose integral part are the process, leaders, managers, as well as organizational structure, organizational culture, brand, intellectual property and so on. Consumers, systematized according to market segments, represent another important driving force of the company.

The new organizational structure and business strategies require a new system of performance measures. Historically, USM\&R relied on functionally measure that included: production and distribution costs, margins and sales volume, as well as indicators of the environment and safety for the group staff responsible for environmental, health and safety. McCool was dissatisfied with these indicators, stating: „We still have the mentality of the controller, revise the past rather than to lead to future. Functional indicators do not communicate what we are. I do not want to functional measures reinforce the mentality of the controller. I want to be part of the process of communication through which everyone in the organization can understand and implement the strategy. We need better measures so that the planning process can be linked to actions, to encourage people, which is dedicated to the organization." Baker also pointed the need for new indicators. „Marketing does not want to lose fuel dealers. But we do not have any focus on measures of quality dealers, so often assign franchise to dealers who are not at the level of the brand image. In addition, the strong strive for short-term profits, so when volume sales falls, people from marketing compensate for the price increases. This can be done in the short term because of the strength of our brand, but in the long run this type of action is untenable."

Mid in 1993 by examining the effectiveness and efficiency of the financial analysis for the whole division, came to the conclusion on their soundness, with a reference avalanche of criticism on the incoherence with business strategy. Late in 1993 approached to the study of the BSC to thinking: „This may be what has been seeking. Our focus is frequently changed, and nothing we do is not related to the mission. The BSC is a process that links the measure with the mission and strategy of the organization. It can allow us to put towards the implementation of new strategies and allow focus on the direction in which we want to move."

Senior management team of USM\&R in 1994 launched a BSC project, hiring Renaissance Solution consulting company, with David Norton, to assist 
the process. At the same time started with the interview with all the members of the leadership team in order to gain insight into their views on the new strategy. The team synthesized the information from the interviews, and with the participation of Norton held several workshops to develop specific goals and performance measures for the four perspectives of the BSC, which contained an active dialogue and debate on the implications of the new strategy. Forcing managers to express their strategy by objectives in the four perspectives really achieved compliance with the new strategy.

The fact that the division has two types of customers had to be a significant aspect of the USM\&R Scorecard in order to incorporate the strategic goals and performance measures for both types. Direct customer is a wide network of franchised dealers who buy fuel from Mobil. The second type of customers, are millions of consumers who purchase Mobil products from independent dealers and retailers.

The team responsible for the development of USM\&R Scorecard is divided into eight sub-teams to enhance and refine strategic objectives and corresponding measures: financial team (led by vice president of strategic planning); two teams of buyers - one focused on the dealers, other on end-users; production team - focused on production costs and other performance measures of refineries; delivery team focused on the inventory management and shipping costs; environment, safety and health team; human resources team and information technology team. Each of sub-teams identified goals and performance measures in their area of management.

In August in 1994. eight sub-teams developed specific strategic objectives for the four BSC perspectives and choosing an initial set of measures associated with these goals. The strategic goals formulated as follows:

\section{THE AREA OF FINANCE:}

\section{Return on capital employed}

„To achieve a sustainable rate of return on capital employed (ROCE), which will constantly be among the best in the U.S. downstream industry, but not less than the agreed corporate objectives for ROCE of $12 \%$."

\section{Cash -flow}

„Manage by operations in order to generate enough cash to cover at least capital expenditures, net financing costs and the portion of the dividend."

\section{Profitability}

„Continuous increase of profitability by generating integrated net margin that will constantly be the two best results in the U.S.." 


\section{The lowest cost}

„To achieve a sustainable competitive advantage by integrating different parts of the value chain in order to achieve the lowest fully allocated total cost in accordance with the supplied value."

\section{Profitable growth}

„The growth of the business by increasing the volume faster than the industry average by searching for income opportunities in line with the overall strategy division."

\section{AREA OF CUSTOMERS:}

\section{Constantly marvel targeted customer}

„To identify and meet the value proposition to target customers.“

\section{Improve the profitability of dealers and wholesale}

„By providing the required products and services, and by facilitate the development of business competencies, improve the profitability of our dealers and wholesaler."

\section{AREA OF INTERNAL PROCESSES:}

\section{Marketing}

„The development of supply and alternative profit centers (APC) - the development of innovative and mutually profitable products and services."

„The development of the franchise and to achieve the level of quality as the best wholesale branches out.“

\section{Production}

„Lower costs with faster production - competitive advantage through increased gross margin and decrease operating costs."

„Better performance of hardware - optimal refinery.“

„Safety - eliminating workplace injuries through education and prevention.“

\section{Supply, Trading and Logistics}

„The reduction of storage costs - lower the cost of admission and transportation."

„Optimization of trading - maximization spot market realization.“

„Inventory management - Inventory optimization with a satisfactory level of service." 


\section{To improve the performance of health, safety and environment}

„Being a good employer and neighbor with a commitment to the safety of the plant and the active concern about the impact on the environment."

\section{Quality}

„Operations management to provide a quality service with quality business processes.“

\section{AREA OF LEARNING AND GROWTH:}

\section{Involvement in the organization}

„Promoting the organization's strategy and create a climate in which employees are motivated and authorized to strive for the realization of the vision."

\section{Core competencies and skills}

- ,integrated view - to encourage a greater understanding of business,

- excellence function - to develop the required level of skills and competence to execute the vision and

- leadership - developing of leadership skills to articulate a vision and promoting integrated business thinking."

\section{Access to strategic information}

„To develop the support necessary to execute the strategy.“

The initial set of appropriate performance measures is shown in Table 3.

Table 3. Correlation between performance measures and goals (Simons, 2000)

\begin{tabular}{||l|l||}
\hline Goals & Measures \\
\hline $\begin{array}{l}\text { FINANCE } \\
\text { Cash-flow }\end{array}$ & ROCE \\
& Cash-flow without dividends \\
Cash-flow from dividends & \\
Profitability & $\begin{array}{l}\text { Profit (after tax) } \\
\text { Net margin (cents per gallon before } \\
\text { taxes) } \\
\text { Net margin, a rating of } 6\end{array}$ \\
& $\begin{array}{l}\text { Total operating costs } \\
\text { (cents per gallon) }\end{array}$ \\
The lowest cost & $\begin{array}{l}\text { Gasoline sales growth in } \% \\
\text { Profitable growth }\end{array}$ \\
& Lubricant sales growth in $\%$ \\
\hline
\end{tabular}




\begin{tabular}{|c|c|}
\hline $\begin{array}{l}\text { CUSTOMERS } \\
\text { Constantly marvel targeted customer }\end{array}$ & $\begin{array}{l}\text { Share segments } \\
\text { Road Warriors (\%) } \\
\text { true blues }(\%) \\
\text { f3 generation (\%) } \\
\text { mystery shopper (\%) } \\
\text { Total gross profit }\end{array}$ \\
\hline $\begin{array}{l}\text { PROCESSES } \\
\text { Development of products and services } \\
\text { of profit centers }\end{array}$ & $\begin{array}{l}\text { Gross margin by prof. center per month } \\
(\$)\end{array}$ \\
\hline $\begin{array}{l}\text { Lower production costs compared to } \\
\text { the competition }\end{array}$ & $\begin{array}{l}\text { ROCE by refineries (\%) } \\
\text { Expenditures by refineries }\end{array}$ \\
\hline $\begin{array}{l}\text { To improve the performance of } \\
\text { health, safety and environment }\end{array}$ & $\begin{array}{l}\text { Environmental incident } \\
\text { Security incidents by the refineries } \\
\text { (days delay) }\end{array}$ \\
\hline The reduction of storage costs & $\begin{array}{l}\text { Storage costs compared to the best } \\
\text { competitors (cents per gallon) }\end{array}$ \\
\hline Inventory management & $\begin{array}{l}\text { The level of inventories } \\
\text { Stocks availability index (\%) }\end{array}$ \\
\hline Quality & Quality index \\
\hline \multicolumn{2}{|l|}{ LEARNING AND GROWTH } \\
\hline Involvement in the organization & Motivation of employees index \\
\hline Core competencies and skills & The availability of strategic competence (\%) \\
\hline Access to strategic information & Strategic systems Availability (\%) \\
\hline
\end{tabular}

Performance measures in the field of finance are associated with the set strategic goals, so that to increase the return on capital employed corresponds to the ROCE measure; improving of cash flow is monitored through measures cash-flow with and without dividends; profitability by the net profit and profit rate; achieving of lower costs refers to the need to monitor the overall operating costs, and the objective of profitable growth is associated with measures such as the percentage increase in sales of various derivatives.

Within the field of customers, achieving the goal of a continuous thrill of the target customer is monitored by proportional share of segments on that focused new strategy, while improving the profitability of dealers and wholesale evaluated on the basis of gross profit. 
In the area of internal processes, according to the driving force, mainly associated goals of optimum operating of profit centers as narrow organizational parts. In this regard, the development of products and services of profit center is best monitored by the rate of profit per profit center; achieving lower production costs than the competition can be measured using the ROCE for refineries; improving the performance of health, safety and the environment - by environmental and safety incidents in delay days; goal of reduce of the storage cost is monitored by storage costs compared to the best competitors; efficiency of inventory management - by stock levels and inventory availability index, and quality by appropriate quality index.

The objectives in the field of learning and growth, as well as involvement in the organization, core competencies and skills and access to strategic information, starting with the key success factors can be observed by measures such as employee motivation index, percentage availability of strategic competence and percentage availability of strategic information systems.

The teams also identified new mechanisms needed to support the required performance measures. For example, a strategic objective to thrill customers into three segments requires from all Mobil stations, fast service, friendly staff and reward loyalty. At that time there was no measure that would evaluate the performance of dealers in these critical processes. Subsoil focus on customers has developed „mysterious buyer program“ by which once a month when purchasing fuel and food evaluated the performance of dealer related to stations exterior, servicing, sales office, staff, toilets. These ratings used as performance measures in the customer perspective of the BSC. Subsoil focused on dealers has launched an initiative to support the strategic aim of developing dealers and created instruments that will allow people in marketing evaluation and work with dealers to improve performance in seven business areas: financial management, service stations, personnel management, car wash, stores, shopping fuels and improving the customer experience. Marketing representatives will assign rating to dealers in order to identify existing opportunities and benefits, all in order to increase the profit performance of dealers and wholesale of offers Mobil, measured by gross profits of dealers and monthly gross margin of alternative profit centers - shops and service points.

Simultaneously with the development of USM\&R Scorecard was launched and the development of business units BSC, by translating strategic themes defined at the level of division at the local goals and measures that will reflect the specific conditions and the competitive environment of each unit. In this regard, McCool said: „Mobil in the Midwest is not the same as Mobil in New England or the west coast. In each market, customers are looking for various services, competitors vary in regions with different of the economics of business. We do not want to dictate solutions from the center. We have a basic strategy and a set of utilities that can offer to each business unit.“ 
Business units Scorecard reflects the USM\&R Scorecard with slightly less measures, especially in the perspective of internal business processes, as business units focused on specific functions - such as regional sales and marketing, processing and distribution - so that the full range of internal measures are not relevant to each of them. Strategic and operational control based on this set of measures system performance greatly contribute to the efficiency of this control at the company as a whole and for reaching the strategic goals.

Exxon Mobil in 2012., with total revenue of 420 billion U.S.\$, total assets of 333 billion U.S.\$ and total employment of 77 thousand employees, was among the top ten leading economic entities in the world.

\section{Conclusion}

Multinational companies provide a powerful process of international integration and the emergence of the global economy, whose essence is the realization of national interests and economic expansion, primarily to home countries. By the new strategy of increased engagement in the development of new technologies, multinational companies succeed in the current crisis not only maintain but also increase the level of their profit margins, and by its longterm strategic aim to meet the needs of consumers for ethically and environmentally responsible approach to business.

Strategic management accounting in any multinational company must meet the unique information needs of its central management and adapt performance measurement. Strategic management accounting information can provide for central management of multinational companies integrating of subsidiaries in centralized organizational milieu and establish highly coordinated relationships between them. This role strategic management accounting can be successfully played exclusively by combining meaningful financial and non-financial performance measures.

Successful implementation and development of an integrated performance measurement system is based on the respect of creating value for all stakeholders, the role of senior management and employees, correlation of measurement, reporting and improvement of performance and the relationship of performance measures to the chosen strategy. The importance of an integrated performance measurement system is minimal if it is not associated with the current key success factors of the company, the chosen strategy and the ultimate goal of creating value. 


\section{References}

Dressler, S. (2004) Strategy, Organization and Performance Management - from basics to best practice. Florida: Universal Publishers Boca Raton.

http://unctad.org/Sections/dite_dir/docs/WIR2013/WIR13_webtab28.xls (15.03.2014.)

Kaplan, R. and Norton, D. (2008) The Execution Premium - Linking Strategy to Operations for Competitive Advantage. Boston, Massachusetts: Harvard Business Pres.

Marković, I. (2003) Cena kao faktor konkurentnosti u novim uslovima poslovanja. Ekonomske teme (1): 85-95.

Marković, I. (2003) Intrasektorska razmena u uslovima globalizacije. Ekonomske teme (2): 277-283.

Marković, I. (2008) Kako se mogu smanjiti troškovi dužničke krize? Ekonomske teme (1): 67-76.

Marković, I. (2013) Proces of Regionalization in the Global Economy. Vrnjačka Banja: 3rd International Conference Economics and Management-Based on New Technologies EMoNT, 278-285.

Mendoza, C. (2002) Tableau de Bord et Balanced Scorecard. G.R.E. Paris.

Milićević, V. (2003) Strategijsko upravljačko racunovodstvo. Beograd: Ekonomski fakultet.

Nanni, A., Dixon, R. and Vollmann, T. (1992) Integrated Performance Measurement: Management Accounting to Support the New Manufacturing Realities. Journal of Management Accounting Research, Fall, Vol. 4, pp. 9-22.

Parmenter, D. (2007). Key Performance Indicators - Developing, Implementing and Using Winning KPIs. Inc: John Wiley and Sons.

prezi.com/.../mobil-usmra-linking-the-balanced-s (25.03.2014.)

Shank, J. K., Govindarajan, V. (1993). Strategic Cost Management: The New Tool of Competitive Advantage. USA: The Free Press.

Simons, R. (2000) Performance Measurement and Control Systems for Implementing Strategy, Text and Cases. New Jersey: Prentice Hall.

Todorović, M. and Marković, I. (2001). Konkurencija na svetskom tržištu u uslovima globalizacije. Ekonomske teme (1-2): 83-89.

www. ftp://27.32.98.129/ (11.03.2010.) Neely, A., Gregory, M. and Platts, K. (1995). Performance measurement system design - A literature review and research agenda. International Journal of Operations \& Production Management, 15 (4): 80-116.

www.authorstream.com (21.03.2014.) 


\section{ULOGA STRATEGIJSKOG UPRAVLJAČKOG RAČUNOVODSTVA U MERENJU I KONTROLI PERFORMANSI MULTINACIONALNIH KOMPANIJA}

Apstrakt: Tip i količina informacija koje su potrebne vrhovnom menadžmentu velikih kompanija prevashodno je određen ulogom pojedinih menadžera. Tako, menadžerima na vrhu hijerarhijske lestvice $\mathrm{u}$ kompleksnim preduzećima neophodne su informacije koje se razlikuju od informacija menadžera pojedinih divizija ili strategijskih poslovnih jedinica. Polazeći od tih zahteva, strategijsko upravljačko računovodstvo je razvilo brojne načine za obezbeđivanje informacija namenjenih oblikovanju korporativnih strategija. S tim u vezi, u radu će biti razmotreni različiti aspekti merenja performansi multinacionalnih kompanija, kao i zadaci koje strategijsko upravljačko računovodstvo treba da ispuni u okviru njih. Imajući u vidu navedene činjenice, glavni cilj rada se sastoji u sagledavanju značaja koji strategijsko upravljačko računovodstvo ima za uspešno upravljanje performansama multinacionalnih kompanija. Adekvatnom primenom teorijskih koncepata i izabranih metoda istraživanja, od rada se očekuje da proširivanjem domaće literature iz ove oblasti upozna našu privrednu javnost sa ulogom strategijskog upravljačkog računovodstva u merenju i kontroli performansi multinacionalnih kompanija.

Ključne reči: strategijsko upravljačko računovodstvo, merenje, kontrola, performanse, multinacionalne kompanije. 